\title{
UNDERSTANDING THE FACTORS THAT AFFECT FOREIGN DIRECT INVESTMENT IN TURKEY BY USING MARS METHOD
}

\author{
TÜRKIYE'NIN DOĞRUDAN YABANCI YATIRIMLARINI ETKILLEYEN \\ FAKTÖRLERIN MARS YÖNTEMİ İLE BELIIRLENMESİ
}

\author{
Sinemis ZENGIN* \\ Serhat YÜKSEL ${ }^{* *}$ \\ Mustafa Tevfik KARTAL ${ }^{* * *}$
}

\begin{abstract}
Increasing foreign direct investment amount is very significant especially for developing countries in order to improve economy. Because of this situation, defining the factors that affect foreign direct investment is essential. Within this context, the main purpose of this study is to identify the influencing factors of foreign direct investment in Turkey. Within this scope, annual data for the periods between 1988 and 2015 was analyzed in this study. In addition to this situation, Multivariate Adaptive Regression Splines (MARS) method was used so as to achieve this objective. According to the results of the analysis, it was determined that current account deficit problem of Turkey affects foreign direct invest negatively. It was identified that if the ratio of current account deficit to total GDP is higher than " 3.57 ", foreign direct investment goes down. This result shows that foreign investors do not prefer to make investment since current account deficit increases fragility in the economy and it is considered as the leading indicator of the economic crisis. While considering the results of this study, it was recommended that current account deficit problem should be minimized to attract foreign investors make investment in Turkey.
\end{abstract}

Keywords: Foreign Direct Investment, MARS, Turkey

JEL Classification: E22, E27, F21

\footnotetext{
* Ph.D. in Banking, sinemiszengin@gmail.com

** Assistant Professor, İstanbul Medipol University, The School of Business, serhatyuksel@medipol.edu.tr

${ }^{* * *}$ Ph.D. in Banking, mustafatevfikkartal@gmail.com
} 


\section{Öz}

Doğrudan yabancı yatırımların artırılması konusu özellikle gelişmekte olan ülkeler için ekonomilerinin büyümesi adına oldukça önemlidir. Bundan dolayı, doğrudan yabancı yatırımları etkileyen faktörlerin belirlenmesi önem arz etmektedir. Bu çerçevede, çalışmanın amacı Türkiye’nin doğrudan yabancı yatırım miktarına etki eden hususların analiz edilmesidir. Bu kapsamda, ilgili çalışmada 1988-2015 dönem aralığındaki yıllık veriler kullanılmıştır. Belirtilen hususa ek olarak, MARS sistemi kullanılarak çalışmanın amacına ulaşılmaya çalışılmıştır. Elde edilen analiz sonuçlarına göre, Türkiye'deki cari işlemler açığı probleminin doğrudan yabancı yatırımları olumsuz yönde etkilemektedir. Cari işlemler açığı rakamının toplam GSYİH’ye oranının 3.57’yi geçmesi durumunda doğrudan yabancı yatırımların azaldığı görülmektedir. Bahsedilen bu sonuç dikkate alındığında, cari işlemler açığı rakamının yüksek olduğu durumda yabancı yatırımcıların Türkiye’yi tercih etmedikleri anlaşılmaktadır. Çalışmada elde edilen bu sonuçlar dikkate alındığında, Türkiye’deki doğrudan yabancı yatırımların artırılması için öncelikle cari işlemler açı̆̆ı probleminin çözülmesi ön plana çıkmaktadır.

Anahtar Kelimeler: Doğrudan Yabancı Yatırım, MARS, Türkiye

JEL Sınıflaması: E22, E27, F21

\section{Introduction}

Especially after globalization, the popularity of international trade increased very much (Storper, 1992, 60). According to World Bank data, the amount of total export in the world went up from 2.43 trillion USD in 1980 to 21.44 trillion USD in 2015. On the other side, import amount in the world was 20.64 trillion USD although it was 2.41 trillion USD in 1980. This dramatic increase in international trade provided many benefits to various parties. First of all, this situation brought a significant chance for the investors to achieve new markets. In addition to this aspect, countries had a chance to improve their economies with the help of foreign investors.

Developing countries are the countries which have low level of industrialization unlike developed countries (Monteiro et. al., 2004, 940). In other words, these countries try to improve their economies because they have a low level of living standards. As it can be understood from the definition, developing countries need foreign investors in order to have higher economic growth. For this purpose, authorities of most developing countries implemented important policies to attract the attention of the foreign investors.

Foreign investment refers to the situation that company from one country makes investment to another country (Aitken, 1997, 103). In other words, foreign investment occurs when a foreign company starts a business or purchase another company in different country. As it can be realized from the definitions, foreign investment plays an essential role regarding economic growth of a developing country. The main reason behind this situation is that developing countries should reach necessary sources in order to develop their economies. 
Foreign investment mainly divides into two different areas, which are indirect and direct foreign investment. With respect to the foreign indirect investment, foreign investors buy the government bonds and stocks of the companies in another country (Karikari, 1992, 8). Because of this situation, it is also called as foreign portfolio investment. Therefore, it can be said that in this kind of investment, investors may easily sell these investments. Owing to this risky condition, it is not a preferable for a country.

On the other side, foreign direct investment includes physical investment in a foreign country (Borensztein et. al., 1998, 117). That is to say, opening a business, buying another companies and establishment a branch in a foreign company are the main examples of foreign direct investment. As it can be understand from these descriptions, foreign direct investment refers to the long term investment. Due to this situation, it is a favored investment for the countries. The main reason is that there is not a risk of easily outflow of foreign direct investment.

Turkey is also a developing country which tries to improve its economy. Owing to this issue, Turkey attempts to attract foreign investors to make investment in the country. It can be seen that there is an important development in these works of Turkey especially after 1980s. In those years, Turkey decided to implement a liberalized economy. For this purpose, it was decided to take some actions so as to increase foreign investments. As a result of these actions, it was seen that there was a significant increase in the amount of foreign investment after these years (Elveren and Galbraith, 2009, 177).

While considering the aspects emphasized above, it can be understood that foreign investment is essential especially for developing countries. Because of this situation, studies that focus on the determinants of foreign direct investment play an important role for this issue. Parallel to this condition, in this study we aimed to analyze the influencing factors of foreign direct investment in Turkey. In order to achieve this objective, Multivariate Adaptive Regression Splines (MARS) model was used in the analysis process. As a result of this analysis, it will be possible to make some suggestions to increase foreign direct investment in Turkey. Regarding the identifying the determinants of foreign direct investment, this model was firstly used in this study. Due to this issue, it was thought that this study will make an important contribution to the literature.

The paper is organized as follows. After introduction part, we will explain the details of similar studies in the literature. In the third part, we will give information about the changes of foreign direct investment amount in Turkey over the years. In addition to them, the fourth part includes research and application to identify the influencing factors of foreign direct investment in Turkey. Finally, the results of the analysis were given at conclusion.

\section{Literature Review}

Foreign direct investment is a subject that was attracted the attention of many researches in the literature. The details of some of these studies were given on table 1 . 
Table I: Studies Related to Foreign Direct Investment

\begin{tabular}{|c|c|c|c|c|}
\hline Author & Year & Scope & Method & Conclusion \\
\hline Agarwal & 1980 & Germany & Survey & $\begin{array}{l}\text { It was concluded that political instability and cheap labor } \\
\text { are important determinants of foreign direct investment. }\end{array}$ \\
\hline $\begin{array}{l}\text { Schneider and } \\
\text { Frey }\end{array}$ & 1985 & $\begin{array}{l}80 \text { less develo- } \\
\text { ped countries }\end{array}$ & Regression & $\begin{array}{l}\text { They concluded that FDI is influenced by GDP growth } \\
\text { rate and current account deficit. }\end{array}$ \\
\hline Tsai & 1991 & Taiwan & Regression & $\begin{array}{l}\text { It was defined that increase in GDP growth does not af- } \\
\text { fect FDI directly. }\end{array}$ \\
\hline Özağ & 1994 & Turkey & Regression & $\begin{array}{l}\text { It was determined that GDP growth influences FDI po- } \\
\text { sitively. }\end{array}$ \\
\hline $\begin{array}{l}\text { Terzi and Gü- } \\
\text { naydın }\end{array}$ & 1997 & Turkey & Regression & $\begin{array}{l}\text { They reached a conclusion that } 1 \% \text { increase in GDP } \\
\text { growth causes FDI to go up about } 1.765 \% \text {. }\end{array}$ \\
\hline Yavan and Kara & 2003 & Turkey & $\begin{array}{l}\text { Literature re- } \\
\text { view }\end{array}$ & $\begin{array}{l}\text { It was determined that industry size is a significant aspect } \\
\text { for foreign investors. }\end{array}$ \\
\hline Morisset & 2003 & USA & Regression & $\begin{array}{l}\text { It was concluded that foreign direct investment is positi- } \\
\text { vely correlated with investment incentives activities. }\end{array}$ \\
\hline Kaya and Yılmaz & 2003 & Turkey & Regression & $\begin{array}{l}\text { Economic growth positively affects foreign direct invest- } \\
\text { ment. }\end{array}$ \\
\hline İnsel and Sungur & 2003 & Turkey & $\begin{array}{l}\text { Granger } \\
\text { Causality } \\
\text { Analysis } \\
\end{array}$ & $\begin{array}{l}\text { They defined that increase in growth, consumption, bank } \\
\text { interest rate and total loans affect FDI. }\end{array}$ \\
\hline Kurtaran & 2007 & Turkey & Regression & $\begin{array}{l}\text { It was identified that investment incentives play an impor- } \\
\text { tant role for foreign investors in Turkey. }\end{array}$ \\
\hline $\begin{array}{l}\text { Dumludağ and } \\
\text { Şükrüoğlu }\end{array}$ & 2007 & Turkey & Regression & $\begin{array}{l}\text { They concluded that internal and external conflict has a } \\
\text { significant impact on foreign direct investment. }\end{array}$ \\
\hline Kar and Tatlısöz & 2008 & Turkey & Regression & $\begin{array}{l}\text { They reached a conclusion that international reserves, } \\
\text { economic growth and investment incentives positively af- } \\
\text { fect foreign direct investment. }\end{array}$ \\
\hline Alagöz et. al. & 2008 & Turkey & Regression & $\begin{array}{l}\text { They defined that economic growth does not affect fore- } \\
\text { ign direct investment. }\end{array}$ \\
\hline Çak and Karakaş & 2009 & Turkey & Regression & $\begin{array}{l}\text { They concluded that economic growth, unemployment } \\
\text { rate, corporate tax rate, population growth rate and infla- } \\
\text { tion rate are main determinants of foreign direct invest- } \\
\text { ment. }\end{array}$ \\
\hline $\begin{array}{l}\text { Zurawicki and } \\
\text { Habi }\end{array}$ & 2010 & USA & $\begin{array}{l}\text { Descriptive } \\
\text { Statistics }\end{array}$ & $\begin{array}{l}\text { They concluded that there is not a relationship between } \\
\text { corruption and foreign direct investment. }\end{array}$ \\
\hline Bal and Göz & 2010 & Turkey & $\begin{array}{l}\text { Descriptive } \\
\text { Statistics }\end{array}$ & $\begin{array}{l}\text { It was identified that there is an increase in foreign direct } \\
\text { investment of Turkey regarding real estate sector. }\end{array}$ \\
\hline Delice and Birol & 2011 & Turkey & Bound test & $\begin{array}{l}\text { It was determined that there is a positive relationship } \\
\text { between foreign direct investment and export in the long } \\
\text { run. }\end{array}$ \\
\hline Ekinci & 2011 & Turkey & $\begin{array}{l}\text { Granger } \\
\text { Causality } \\
\text { Analysis } \\
\end{array}$ & $\begin{array}{l}\text { It was defined that economic growth affects foreign direct } \\
\text { investment. }\end{array}$ \\
\hline Saray & 2011 & Turkey & $\begin{array}{l}\text { Cointegra- } \\
\text { tion Analysis }\end{array}$ & $\begin{array}{l}\text { It was concluded that there is not a relationship between } \\
\text { foreign direct investment and unemployment rate. }\end{array}$ \\
\hline
\end{tabular}


Finansal Araştırmalar ve Çalışmalar Dergisi • Cilt: 10 • Sayı: 18 • Ocak 20 I8, ss. 177-192

\begin{tabular}{|c|c|c|c|c|}
\hline Author & Year & Scope & Method & Conclusion \\
\hline Sarısoy and Koç & 2010 & $\begin{array}{l}21 \text { OECD } \\
\text { countries }\end{array}$ & Regression & $\begin{array}{l}\text { It was defined that foreign direct investment increases the } \\
\text { corporate tax revenues of the countries. }\end{array}$ \\
\hline Arık et. al. & 2014 & Turkey & Regression & $\begin{array}{l}\text { It was determined that economic stability is a significant } \\
\text { indicator of FDI. }\end{array}$ \\
\hline Udenze & 2014 & USA & Regression & $\begin{array}{l}\text { It was defined that the level of corruption negatively affe- } \\
\text { cts foreign investors. }\end{array}$ \\
\hline Quazi & 2014 & USA & Regression & $\begin{array}{l}\text { It was identified that foreign investors do not prefer to } \\
\text { make investment to the companies that have corruption } \\
\text { problem. }\end{array}$ \\
\hline Emir and Kutlu & 2014 & Turkey & $\begin{array}{l}\text { Granger } \\
\text { Causality } \\
\text { Analysis }\end{array}$ & $\begin{array}{l}\text { It was concluded that there is a causality relationship } \\
\text { between economic growth and FDI. }\end{array}$ \\
\hline Çetin and Seker & 2014 & Turkey & VAR & $\begin{array}{l}\text { It was determined that financial development of the com- } \\
\text { pany positively affects FDI. }\end{array}$ \\
\hline $\begin{array}{l}\text { Tekin and Şan- } \\
\text { lisoy }\end{array}$ & 2016 & Turkey & Regression & $\begin{array}{l}\text { After 1980, there was a positive relationship between the } \\
\text { patent and foreign direct investment. }\end{array}$ \\
\hline Aytun et. al. & 2015 & Turkey & Regression & $\begin{array}{l}\text { Telecommunication is a significant sector that attracts the } \\
\text { attention of foreign investors in Turkey }\end{array}$ \\
\hline $\begin{array}{l}\text { Iqbal and Mah- } \\
\text { mood }\end{array}$ & 2016 & Pakistan & VECM & $\begin{array}{l}\text { They reached a conclusion that economic growth affects } \\
\text { foreign direct investment positively. }\end{array}$ \\
\hline $\begin{array}{l}\text { Başar and Öz- } \\
\text { kllbaç }\end{array}$ & 2016 & Turkey & Regression & $\begin{array}{l}\text { It was determined that there is not long term relationship } \\
\text { between foreign direct investment and economic growth. }\end{array}$ \\
\hline $\begin{array}{l}\text { Okereke and } \\
\text { Ebulison }\end{array}$ & 2016 & Nigeria & $\begin{array}{l}\text { Cointegra- } \\
\text { tion Analysis }\end{array}$ & $\begin{array}{l}\text { Volatility in currency exchange rate affects foreign inves- } \\
\text { tors negatively. }\end{array}$ \\
\hline Bal and Akça & 2016 & Turkey & Regression & $\begin{array}{l}\text { It was concluded that the size of the market is important } \\
\text { for foreign direct investment. }\end{array}$ \\
\hline Castellani et. al. & 2016 & $\begin{array}{l}\text { European } \\
\text { Union }\end{array}$ & Regression & $\begin{array}{l}\text { It was identified that regions, which are specialized in ma- } \\
\text { nufacturing, attract the attention of foreign investors. }\end{array}$ \\
\hline Eshghi et. al. & 2016 & $\begin{array}{l}5 \text { European } \\
\text { countries }\end{array}$ & Regression & $\begin{array}{l}\text { They defined that corporate income tax negatively affects } \\
\text { foreign direct investment. }\end{array}$ \\
\hline Hoa and Lin & 2016 & $\begin{array}{l}\text { Cambodia, } \\
\text { Laos, and } \\
\text { Vietnam } \\
\end{array}$ & Regression & $\begin{array}{l}\text { They reached a conclusion that market size and political } \\
\text { stability influence foreign direct investment. }\end{array}$ \\
\hline Salem and Baum & 2016 & $\begin{array}{l}\text { MENA count- } \\
\text { ries }\end{array}$ & Tobit & $\begin{array}{l}\text { It was defined that political stability is the most important } \\
\text { issue of foreign direct investment. }\end{array}$ \\
\hline $\begin{array}{l}\text { Feng and Min- } \\
\text { gque }\end{array}$ & 2016 & China & Regression & $\begin{array}{l}\text { They determined that economic growth and the size of } \\
\text { the industry are key factors of foreign direct investment. }\end{array}$ \\
\hline Awolusi et. al. & 2016 & $\begin{array}{l}81 \text { Asian and } \\
\text { African count- } \\
\text { ries }\end{array}$ & $\begin{array}{l}\text { Granger } \\
\text { Causality } \\
\text { Analysis }\end{array}$ & $\begin{array}{l}\text { They reached a conclusion that economic stability increa- } \\
\text { ses foreign direct investment. }\end{array}$ \\
\hline Economou et. al. & 2016 & $\begin{array}{l}22 \text { OECD } \\
\text { countries }\end{array}$ & Regression & $\begin{array}{l}\text { It was concluded that the size of the industry affects fore- } \\
\text { ign direct investment positively. }\end{array}$ \\
\hline $\begin{array}{l}\text { Lucke and Ei- } \\
\text { chler }\end{array}$ & 2016 & $\begin{array}{l}65 \text { developing } \\
\text { countries }\end{array}$ & Regression & $\begin{array}{l}\text { They identified that political stability is the main indica- } \\
\text { tor of foreign direct investment. }\end{array}$ \\
\hline
\end{tabular}


As it can be seen from table 1, most of the studies found a relationship between economic growth and foreign direct investment. Schneider and Frey (1985) analyzed the determinants of foreign direct investment in 80 less developed countries. As a result of regression analysis, it was defined that economic growth influences foreign direct investment positively. Özağ (1994), Terzi and Günaydın (1997), Kaya and Yllmaz (2003), Kar and Tatlısöz (2008), Çak and Karakaş (2009), Ekinci (2011), Başar and Özkılbaç (2016) and Feng and Mingque (2016) reached the similar results by using the same method.

Additionally, İnsel and Sungur (2003) and Emir and Kutlu (2014) concluded that GDP growth influences foreign direct investment positively by using Granger causality analysis. Furthermore, Iqbal and Mahmood (2016) used vector error correction model and reached the same conclusion. On the other side, Tsai (1991) made a study in order to identify the influencing factors of foreign direct investment in Taiwan. According to the results of the regression analysis, it was defined that economic growth does not affect foreign direct investment directly. Similar to this study, Alagöz and others (2008) could not also find a relationship between these variables in their study.

In addition to the economic growth, corruption is also another factor which affected foreign direct investment according to the studies in the literature. Udenze (2014) tried to determine the key factors of foreign direct investment in USA. In order to achieve this objective, regression analysis was used in this study. As a result of this analysis, it was determined that the level of corruption negatively affects foreign investors. Moreover, Quazi (2014) also reached the similar conclusion by using the same method. However, Zurawicki and Habib (2010) identified that there is not a relationship between corruption and foreign direct investment.

Furthermore, political stability is another concept that influenced foreign direct investment according to the results of many studies. Agarwal (1980) made a survey analysis to analyze the determinants of foreign direct investment in Germany. It was determined that political instability has a negative impact on foreign direct investment. Additionally, Dumludağ and Şükrüoğlu (2007), Salem and Baum (2016) and Lucke and Eichler (2016) reached the same conclusion by using different methods.

Moreover, economic stability is another aspect that was taken into the consideration by foreign investors. Awolusi and others (2016) made a study so as to understand the main indicators of foreign direct investment in 81 Asian and African countries. In order to achieve this objective, they used Granger causality analysis. As a result of this analysis, it was identified that economic stability increases foreign direct investment. Arık and others (2014) and Delice and Birol (2011) also emphasized this issue in their studies. Parallel to these studies, Okereke and Ebulison (2016) concluded that volatility in currency exchange rate affects foreign investors negatively.

As it can be understood from table 1, there are lots of studies which tried to analyze the key factors of foreign direct investment. It was also determined that regression method was used in most of these studies. Nevertheless, it was identified that Eviews program was used in the analysis process of these studies. Therefore, it can be said that there is a need of a study in which a new and original method is used. 


\section{Foreign Direct Investment in Turkey}

With respect to the foreign direct investment, it is possible to divide Turkish economy in two different periods that are before and after 1980s. From the foundation of the republic in 1923 to 1980s, Turkey was subject to many financial problems due to some reasons, such as great depression in 1929, World War II and Korean War (Okyar, 1979, 325-344). The economic policies after 1960s aimed to protect the domestic market. Because of this condition, government preferred to have restrictive trade regime and this situation caused export oriented industries to become weak. On the other side, In 1970s, government started to support private sectors by providing necessary loans. However, because this plan caused budget deficit, it resulted in high inflation problem in Turkey. As it can be seen from graph 1, there is a radical increase in inflation rate after 1970s (Pamuk, 2007, 3).

Graph I: Inflation Rate of Turkey

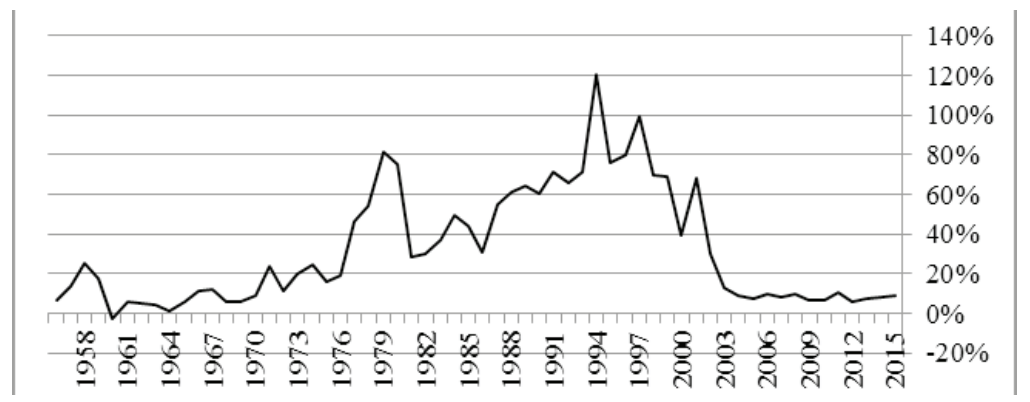

Source: http://www.inflation.eu/inflation-rates/turkey/historic-inflation/cpi-inflation-turkey.aspx

Because of this problem, Turkey needed a new economic program so as to provide economic sustainability. For this purpose, in 1980s, Turkey adapted liberal economic system. Within this scope, the controls over interest and currency exchange rates were eliminated according to the decisions taken in 24 January 1980. These decisions caused foreign direct investment to go up after these years (Elveren and Galbraith, 2009, 183). Graph 2 gives information about the foreign direct investments of Turkey for the periods between 1975 and 2002.

Graph 2: Foreign Direct Investment of Turkey between 1975 and 2002 (USD)

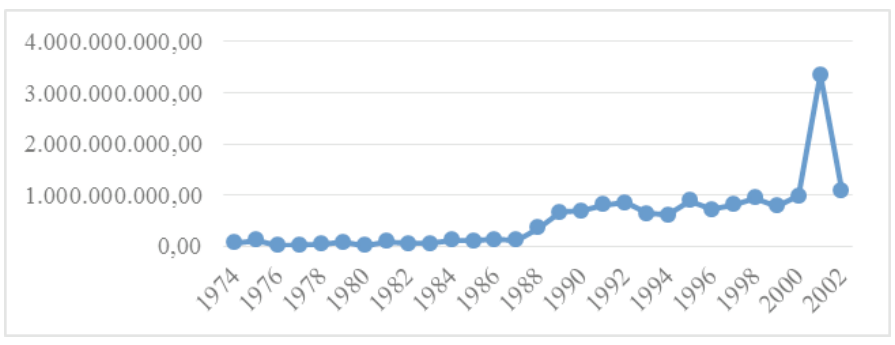

Source: World Bank 
As it can be seen from graph 2, the amount of foreign direct investment rose very much after 1980s. Also, this increase continued until 2001 in which a significant banking crisis occurred in Turkey. Due to this crisis, there was a radical decrease in this amount. Furthermore, graph 3 illustrates the direct foreign investment of Turkey for the years between 2003 and 2015.

Graph 3: Foreign Direct Investment of Turkey between 2003 and 2015 (USD)

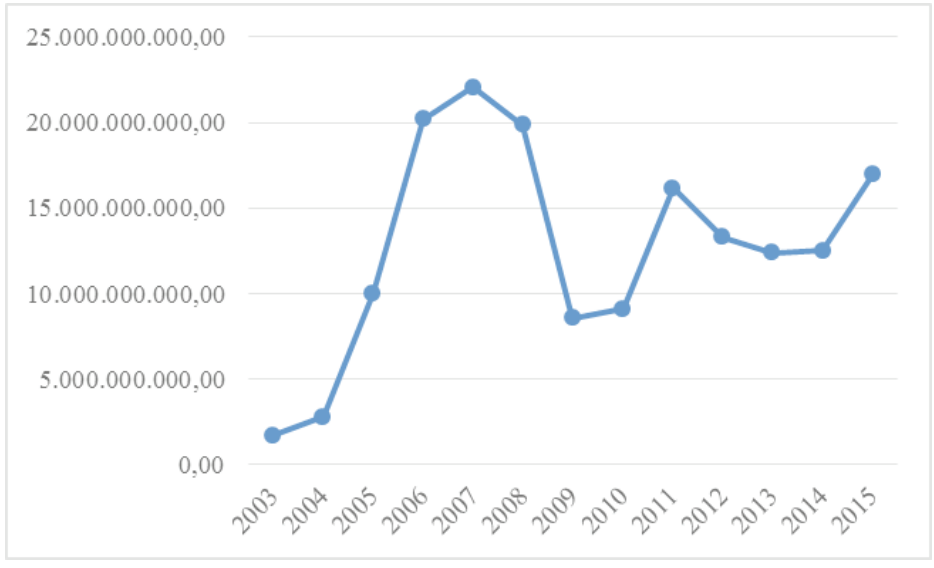

Source: World Bank

After this crisis, Turkey took some new actions related to economy in order to provide economic growth. As an example, banking sector was restructured in Turkey. These actions increased the credibility of Turkey. As a result of this situation, the amount of foreign direct investment went up especially after 2003. As it can be understood from graph 3, this increase went on until 2008. Due to global mortgage crisis occurred in that years, the amount of foreign direct investment decreased very much. Nevertheless, after 2010, it can be said that the amount of foreign direct investment had an increasing trend.

\section{The Methods Used in the Study}

Multivariate Adaptive Regression Splines (MARS) method was developed by Jerome Friedman in 1991. This method is used to understand the relationship between dependent and independent variables (Friedman, 1991, 1). MARS model is detailed on the following equation.

$$
Y=B_{0}+\sum_{n=1}^{K} a_{n} B_{n}\left(X_{t}\right)+\varepsilon
$$

In this equation, "Y" demonstrates the dependent variable. On the other side, "X" refers to the independent variables that have effect on the dependent variable. Moreover, " $\mathrm{B}_{0}$ " represents the constant term while " $\mathrm{a}_{\mathrm{n}}$ " shows the coefficient of nth basis function. Additionally, " $\mathrm{K}$ " explains the number of basis functions and " $\varepsilon$ " demonstrates the error term. 
In the analysis process, firstly, basis functions are developed while considering various combinations of independent variables. This process stops when system reaches the maximum amount of basis functions. Next, system eliminates some basis functions that reduce the level of significance of the model. Consequently, the ideal model can be achieved. This model has the highest $\mathrm{R}^{2}$ and lowest error of estimation (GCV) values.

While creating a model by using MARS method, some subjects should be completed on the system. Within this context, velocity factors, which take value between 1 and 5 , should be chosen as a low value in order to achieve more accurate results (Tunay, 2001, 182-185). In addition to this issue, the space of "maximum interaction among variables" should be completed so as to identify how many variables can be interacted each other (Friedman, 1991, 60).

There are a lot of advantages of using MARS method. Firstly, MARS method eliminates multicollinearity problem which refers to the high correlation between explanatory variables. Furthermore, in MARS method, it is possible for independent variables to take various coefficients for different situations. In addition to this situation, smoothing splines are used in MARS method instead of a straight line to determine the relationship among variables. (Friedman, 1991, 7-60).

In the literature, there are not many studies in which MARS model was used. The main reason behind this situation is that it is a very new method. Tunay (2010), Oktar and Yüksel (2015) and Yüksel and Zengin (2016) used MARS method so as to determine early warning signals of the financial crisis. In addition to those studies, Tunay (2011) and Sephton (2001) used this study to analyze recession. Moreover, Yüksel (2016) identified the determinants of current account deficit in Turkey and Oktar and Yüksel (2016) defined the factors that affect Turkish banks to use derivatives by using this method.

\section{Econometric Analysis}

\section{I. Data}

Annual data for the period between 1988 and 2015 was used in this study. This data was provided from the websites of World Bank and Turkish Statistical Institute. Additionally, with respect to the stationary analysis, Eviews 8 program was used. On the other side, MARS 2.0 program of Salford Company was used in order to understand the relationship between dependent and independent variables.

\subsection{Variables Used in the Study}

In order to reach the purpose of the study, we used log values of foreign direct investment amount of Turkey for the years between 1988 and 2015. Additionally, to determine the influencing factors of foreign direct investment, 7 different independent variables were taken into the consideration as a result of analyzing similar studies in the literature. The details of these variables were given on table 2 . 
Table 2: Independent Variables Used in the Model

\begin{tabular}{|c|c|c|}
\hline $\begin{array}{l}\text { The Name } \\
\text { of the Vari- } \\
\text { ables }\end{array}$ & Explanation & Reference \\
\hline $\begin{array}{l}\text { Current Ac- } \\
\text { count Deficit }\end{array}$ & $\begin{array}{l}\text { Current Account } \\
\text { Deficit / GDP }\end{array}$ & $\begin{array}{l}\text { Agarwal (1980), Schneider and Frey (1985), İnsel and Sungur (2003), Kurta- } \\
\text { ran (2007), Karagöz (2007), Arık et. al. (2014), Çetin and Seker (2014), Başar } \\
\text { and Özkılbaç (2016) }\end{array}$ \\
\hline Bank Loans & Bank Loans/GDP & $\begin{array}{l}\text { İnsel and Sungur (2003), Çetin and Seker (2014), Economou et. al. (2016), } \\
\text { Hoa and Lin (2016) }\end{array}$ \\
\hline Inflation Rate & $\begin{array}{l}\left(\mathrm{CPI}_{\mathrm{t}}-\mathrm{CPI}_{\mathrm{t}-1}\right) / \\
\mathrm{CPI}_{\mathrm{t}-1}\end{array}$ & $\begin{array}{l}\text { Agarwal (1980), İnsel and Sungur (2003), Kaya and Yılmaz (2003), Karagöz } \\
\text { (2007), Çak and Karakaş (2009), Arık et. al. (2014), Çetin and Seker (2014) }\end{array}$ \\
\hline $\begin{array}{l}\text { Unemploy- } \\
\text { ment Rate }\end{array}$ & $\begin{array}{l}\text { Unemployed Pe- } \\
\text { ople/Labor Force }\end{array}$ & Çak ve Karakaş (2009), Ekinci (2011) \\
\hline $\begin{array}{l}\text { Currency Ex- } \\
\text { change Rate }\end{array}$ & $\begin{array}{l}\text { USD/TL Exc- } \\
\text { hange Rates }\end{array}$ & $\begin{array}{l}\text { Özağ (1994), Kaya and Yilmaz (2003), İnsel and Sungur (2003), Karagöz } \\
\text { (2007), Kar and Tatlisöz (2008), Arık et. al. (2014), Awolusi et. al. (2016), Lu- } \\
\text { cke and Eichler (2016), Okereke and Ebulison (2016) }\end{array}$ \\
\hline $\begin{array}{l}\text { Economic } \\
\text { Growth }\end{array}$ & $\begin{array}{l}\left(\mathrm{GDP}_{\mathrm{t}}-\mathrm{GDP}_{\mathrm{t}-1}\right) / \\
\mathrm{GDP}_{\mathrm{t}-1}\end{array}$ & $\begin{array}{l}\text { Agarwal (1980), Schneider and Frey (1985), Özağ (1994), İnsel and Sun- } \\
\text { gur (2003), Kaya and Yllmaz (2003), Dumludağ and Şükrüoğlu (2007), Ka- } \\
\text { ragöz (2007), Kurtaran (2007), Alagöz et. al. (2008), Kar and Tatlısöz (2008), } \\
\text { Çak and Karakaş (2009), Ekinci (2011), Arık et. al. (2014), Çetin and Seker } \\
\text { (2014), Emir and Kutlu (2014), Başar and Özkılbaç (2016), Feng and Min- } \\
\text { gque (2016), Hoa and Lin (2016), Iqbal and Mahmood (2016) }\end{array}$ \\
\hline Interest Rate & $\begin{array}{l}1 \text { Year Interest } \\
\text { Rate of the De- } \\
\text { posits }\end{array}$ & İnsel and Sungur (2003), Awolusi et. al. (2016), Eshghi et. al. (2016) \\
\hline
\end{tabular}

As it can be seen from table 2, we used 7 different independent variables. Current account deficit increases the fragility in the economy (Yüksel, 2016, 102). Because of this situation, there should be negative relationship between current account deficit and foreign direct investment. Furthermore, the effect of bank loans to foreign direct investment can be changed according to the quality of the loans (Çetin and Seker, 2014, 131). If the quality of the bank loans is high, this increases the size of the sector, so it will attract the attention of the foreign investors. On the other hand, when the amount of non-performing loans is high, it will cause foreign direct investment to decrease.

In addition to those variables, because higher inflation and unemployment rates refer to the unfavorable situation, there should be negative relationship between these variables and foreign direct investment (Çak and Karakaş, 2009, 49). Moreover, since high amount of changes in USD/ TL exchange rates show the volatility in the market, this condition will affect foreign investors negatively (Okereke and Ebulison, 2016, 10). On the other side, high economic growth increases stability in the economy. Owing to this aspect, there should be positive relationship between this variable and foreign direct investment. Additionally, higher interest rate has a negative effect on foreign direct investment due to the similar reason (Eshghi et. al., 2016, 111). 


\subsection{Analysis Results and Findings}

In order to analyze the influencing factors of foreign direct investment in Turkey, firstly, we made an analysis to understand whether independent variables are stationary or not. For this purpose, Augmented Dickey Fuller (ADF) and Phillips Perron (PP) unit root tests were used. The results of these tests were demonstrated on table 3.

Table 3: ADF and PP Unit Root Test Results

\begin{tabular}{|l|l|l|l|l|}
\hline \multirow{2}{*}{ Variable 1. } & \multicolumn{3}{|l|}{ Augmented Dickey Fuller (ADF) Test } & Philips Peron Test \\
\cline { 2 - 5 } & $\begin{array}{l}\text { Level Value } \\
\text { (Probability) }\end{array}$ & $\begin{array}{l}\text { First Difference Value } \\
\text { (Probability) }\end{array}$ & $\begin{array}{l}\text { Level Value } \\
\text { (Probability) }\end{array}$ & $\begin{array}{l}\text { First Difference } \\
\text { Value (Probability) }\end{array}$ \\
\hline Current Account Deficit & 0.0080 & - & 0.0079 & - \\
\hline Real Interest Rate & 0.7808 & 0.0095 & 0.7808 & 0.0095 \\
\hline Inflation & 0.0743 & 0.0020 & 0.1819 & 0.0000 \\
\hline Growth Rate & 0.0001 & - & 0.0000 & - \\
\hline Unemployment Rate & 0.3559 & 0.0034 & 0.3141 & 0.0031 \\
\hline USD/TL Currency Exchange Rate & 0.7248 & 0.0057 & 0.6949 & 0.0057 \\
\hline Total Loans & 0.6777 & 0.0000 & 0.9871 & 0.0000 \\
\hline
\end{tabular}

As it can be understood from table 3, probability values of 2 explanatory variables (current account deficit and growth rate) are less than 0.05. This situation explains that these variables are stationary on their level values. On the other side, it was also identified that the probability values of other 5 independent variables (real interest rate, inflation, unemployment rate, USD/TL currency exchange rate and total loans) are more than 0.05 . Because they are not stationary on their level values, the first differences of them were used in the analysis.

After unit root tests, we made an analysis in order to see the influencing factors of foreign direct investment in Turkey. Within this context, MARS system provided 8 different models. The details of these models were explained on table 4 .

Table 4: All Models Provided by MARS Method

\begin{tabular}{|c|c|c|c|}
\hline Total Basis Functions & Total Variables & GCV & GCV R $^{\mathbf{2}}$ \\
\hline 8 & 4 & 0.304 & 0.207 \\
\hline 7 & 4 & 0.220 & 0.426 \\
\hline 6 & 4 & 0.173 & 0.548 \\
\hline 5 & 4 & 0.129 & 0.662 \\
\hline 4 & 3 & 0.112 & 0.709 \\
\hline 3 & 2 & 0.105 & 0.726 \\
\hline$* * \mathbf{2}$ & $\mathbf{1}$ & $\mathbf{0 . 1 0 1}$ & $\mathbf{0 . 7 3 6}$ \\
\hline 1 & 1 & 0.212 & 0.446 \\
\hline
\end{tabular}

The model, which is at the bottom of table 4, is called as starting model. This is the first model which was produced by MARS method in the analysis process. It has only one basis function 
and variable. Moreover, MARS system also developed many different models by adding some basis functions to this starting model. Within this scope, the model, which is at the top of table 5, is called as the most complex model. This is the biggest model which was provided by MARS according to the criteria given to the system. After this situation, MARS system started to eliminate some basis functions from this most complex model so as to reach the ideal model. In this process, system excluded some basis functions that have a decreasing effect on GCV $\mathrm{R}^{2}$ value of the model. The model, which has a sign of "**”, is named as the ideal model. As it can be seen from table 4 , it has the lowest GCV and highest GCV $\mathrm{R}^{2}$ value among all models.

Table 5: The Details of the Ideal Model

\begin{tabular}{|l|l|l|}
\hline Variable & Coefficient & $\mathbf{p}$ Value \\
\hline Constant & 10.182 & 0.000 \\
\hline Basis Function 10 & 1.197 & 0.000 \\
\hline Basis Function 12 & -1.210 & 0.000 \\
\hline F Test 56.33 [0.000] GCV 0.101 & \\
$\mathrm{R}^{2} 0.824$ Adj $\mathrm{R}^{2} 0.810$ & & \\
\hline
\end{tabular}

Table 5 gives information about the details of the ideal model. As it can be understood from this table, the ideal model has one constant and two different basis functions. Because p values are less than 0.05 , they are statistically significant. Furthermore, since F value is less than 0.05 , it was defined that the model is statistically significant as a whole. In addition to them, adjusted $\mathrm{R}^{2}$ value shows that the independent variables explain $81 \%$ dependent variable.

Table 6: The Details of the Basis Functions in the Model

\begin{tabular}{|l|l|l|}
\hline Basis Functions & Explanation & Coefficient \\
\hline Basis Function 10 & $\max (0$, Current Account Deficit +3.570$)$ & 1.197 \\
\hline Basis Function 12 & $\max (0$, Current Account Deficit +4.490$)$ & -1.210 \\
\hline
\end{tabular}

Table 6 gives detailed information about the ideal model. As it can be seen from this table there is only one independent variable which affects foreign direct investment in Turkey. In order to make more effective results, the ratio of current account deficit of total GDP was used in the analysis. Moreover, if there is a current account surplus, this ratio takes positive values whereas it is negative in case of current account deficit. This variable was stated on both basis function 10 and 12. According to basis function 10, if this ratio is more than “-3.57", it increases foreign direct investment in Turkey because of the positive coefficient (1.197). However, regarding basis function 12, it was determined that if this value is less than " 3.57 ", there is an inverse relationship between current account deficit and foreign direct investment due to the negative coefficient $(-1.210)$.

As a result of this analysis, it was identified that current account deficit problem of Turkey affects foreign direct invest negatively. It was understood that if the ratio of current account deficit 
to total GDP is higher than " 3.57 ", there will be a decrease in foreign direct investment. On the other hand, foreign direct investment goes up when "current account deficit/GDP" ratio reduces the level behind " 3.57 ". These results refer to the condition that foreign investors prefer to make investment in Turkey when there is not a current account deficit problem. In other words, because current account deficit increases fragility in the economy and it is considered as the leading indicator of the economic crisis, foreign investors do not opt for making investment. Increasing foreign direct investment is a very significant factor to improve the economy. Owing to this situation, while considering the results of this study, it was recommended that current account deficit problem should be disappeared so as to attract foreign investors. Schneider and Frey (1985) and Froot and Stein (1989) reached the same conclusion in their studies.

\section{Conclusion}

We tried to analyze the determinants of foreign direct investment in Turkey. Within this context, annual data for the periods between 1988 and 2015 was analyzed in this study. Moreover, we selected 7 different explanatory variables that may affect foreign direct investment amount. In addition to these issues, we used Multivariate Adaptive Regression Splines (MARS) method so as to achieve this objective.

First of all, we made unit root tests for independent variables in order to understand whether they are stationary or not. Within this scope, Augmented Dickey Fuller (ADF) and Phillips Peron (PP) unit root tests were used. As a result of this analysis, it was defined that 2 variables are stationary on their level values. However, it was also understood that other 5 independent variables are not stationary, so the first differences of them were used in the analysis.

After stationary analysis, we made an analysis by using MARS method so as to determine the key factors that influence foreign direct investment. According to the results of this analysis, it was identified that current account deficit problem influences foreign direct investment. In addition to this aspect, it was also defined that there is an inverse relationship between current account deficit and foreign direct investment owing to the negative coefficient.

These results show that foreign investors prefer to make investment in Turkey when there is not a current account deficit problem. That is to say, current account deficit problem has a negative impact on foreign direct investment since it increases fragility in the economy. Because foreign direct investment plays an important role to improve the economy, it was recommended that Turkey should firstly focus on solving current account deficit problem to attract foreign investors.

\section{References}

AGARWAL, Jamuna P., Determinants of Foreign Direct Investment: A Survey, Weltwirtschaftliches Archiv, 1980, 116(4), s. 739-773.

AITKEN, Brian, HANSON, Gordon H., HARRISON, Ann E., Spillovers, Foreign Investment, and Export Behavior, Journal of International Economics, 1997, 43(1), s. 103-132. 
ALAGÖZ, Mehmet, ERDOĞAN, Savaş, TOPALLI, Nurgül, Doğrudan Yabancı Sermaye Yatırımları ve Ekonomik Büyüme: Türkiye Deneyimi 1992 - 2007, Gaziantep Üniversitesi Sosyal Bilimler Dergisi, 2008, 7 (1), s. 79-89.

ARIK, Şebnem, AKAY, A. Beyhan, ZANBAK, Mehmet, Doğrudan Yabancı Yatırımları Belirleyen Faktörler: Yükselen Piyasalar Örneği, Anadolu Üniversitesi Sosyal Bilimler Dergisi, 2014, 14(2), s. 97 110.

AYTUN, Cengiz, AKIN, Cemil Serhat, UÇAN, Okyay, Gelişmiş ve Gelişmekte Olan Ülkelerde Telekomünikasyon Yatırımları ve Doğrudan Yabancı Sermaye Yatırımları İliş̧isi, Ege Akademik Bakış, 2015, 15(2), s. 207.

AWOLUSI, Olawumi D., PELSER, Theuns G., ADELEKAN, Adedeji Saidi, Determinants of Foreign Direct Investment: New Granger Causality Evidence from Asian and African Economies, Journal of Economics and Behavioral Studies, 2016, 8(1), s. 104-119.

BAL, Harun, AKÇA, Emrah Eray, Doğrudan Yabancı Sermaye Yatırımlarının Belirleyicileri: Seçilmiş Doğu Asya ve Pasifik Ülkelerinden Ampirik Bulgular, Sosyoekonomi, 2016, Vol. 24(30), s. 91-111.

BAŞAR, Selim, ÖZKILBAÇ, Selda Çakıcı, Effects of Outward Foreign Direct Investment of Turkey on Economic Growth and Domestic Investment. Ankara Üniversitesi SBF Dergisi, 2016, 71(1), s. 231247.

BORENSZTEIN, Eduardo, DE GREGORIO, Jose, LEE, Jong-Wha, How Does Foreign Direct Investment Affect Economic Growth?, Journal of International Economics, 1998, 45(1), s. 115-135.

CASTELLANI, Davide, MELICIANI, Valentina, MIRRA, Loredana, The Determinants of Inward Foreign Direct Investment in Business Services Across European Regions, Regional Studies, 2016, 50(4), s. 671-691.

ÇAK, Murat, KARAKAŞ, Mehmet, Doğrudan Yabancı Sermaye Yatırımlarını Belirleyen Unsurlar ve Etkileri, İktisadi ve İdari Bilimler Dergisi, 2009, 26(1), s. 43-54.

ÇETIN, Murat, SEKER, Fahri, Ticari Açıklık ve Finansal Gelişmenin Doğrudan Yabancı Yatırımlar Üzerindeki Etkisi: OECD Ülkeleri Üzerine Dinamik Panel Veri Analizi, Atatürk Üniversitesi İktisadi ve İdari Bilimler Dergisi, 2014, 28(1), s. 125-147.

DELİCE, Güven, BİROL, Yunus Emre, Dolaysız Yabancı Sermaye Yatırımları ve Dış Ticaret Bilançosu: Türkiye Üzerine Bir Uygulama, 2011, Uludağ Üniversitesi İktisadi ve İdari Bilimler Dergisi, 2011, 30(2), s. 1-28.

DUMLUDAĞ, Devrim, ŞÜKRÜOĞLU, Deniz, The Impact of Macroeconomic And Institutional Variables on Foreign Direct Investment Flows in Emerging Markets, İktisadi ve İdari Bilimler Dergisi, 2007, 23(2), s. 133-166.

ECONOMOU, Fotini, HASSAPIS, Christis, PHILIPPAS, Nikolaos, TSIONAS, Mike, Foreign Direct Investment Determinants in OECD and Developing Countries, Review of Development Economics, 2016.

EKİNCİ, Aykut, Doğrudan Yabancı Yatırımların Ekonomik Büyüme Ve İstihdama Etkisi: Türkiye Uygulaması (1980-2010), Eskişehir Osmangazi Üniversitesi İktisadi ve İdari Bilimler Dergisi, 2011, 6(2), s. 71-96.

ELVEREN, Adem Y, GALBRAITH, James K., Pay Inequality in Turkey in the Neo-liberal Era, 1980-2001, The European Journal of Comparative Economics, 2009, 6(2), s. 177-206.

EMİ, Mustafa, KUTLU, Melih, Relationship Between FDI and Economic Growth in Developing Countries, Journal of Economics, Finance and Accounting, 2014. Volume: 1, Issue: 1, s. 38-45. 
ESHGHI, Golpira, ESHGHI, Abdolreza, LI, Rui, Corporate Income Tax as a Determinant of Foreign Direct Investment in Central and Eastern Europe, European Journal of Business and Social Sciences, 2016, 4(11), s. 111-123.

FENG, Yin, MINGQUE, Ye, Location Determinants of Foreign Direct Investment in Services: Do Agglomeration Economies Matter?, China: An International Journal, 2016, 14(2), s. 123-145.

FRIEDMAN, Jerome, Multivariate Adaptive Regression Splines, The Annals of Statistics, 1991, s. 1-67.

FROOT, Kenneth A., STEIN, Jeremy C., Exchange Rates and Foreign Direct Investment: An Imperfect Capital Markets Approach, National Bureau of Economic Research Working Paper, 1989, No: 2914.

HOA, Doan Thi Thanh, LIN, Jan-Yan, Determinants of Foreign Direct Investment in Indochina: A Holistic Approach, International Journal of Business and Applied Social Science, 2016, 2(1), s. 1-10.

IQBAL, Zahid, MAHMOOD, Adil, ARDL Approach for Determinants of Foreign Direct Investment (FDI) in Pakistan (1961-2013): An Empirical Study, Global Journal of Quantitative Science, 2016, 3(2), s. 9-14.

İNSEL, Aysu, SUNGUR, Nesrin, Sermaye Akımlarının Temel Makroekonomik Göstergeler Üzerindeki Etkileri: Türkiye Örneği-1989:III-1999:IV, 2003, (No. 2003/8).

KAR, Muhsin, TATLISÖZ, Fatma, Türkiye'de Doğrudan Yabancı Sermaye Hareketlerini Belirleyen Faktörlerin Ekonometrik Analizi, KMU İİF Dergisi, 2008, 14(1).

KARAGÖZ, Kadir, Türkiye'de Doğrudan Yabancı Yatırım Girişlerini Belirleyen Faktörler: 1970-2005, Journal of Yaşar University, 2007, 2(8), s. 929-948.

KARIKARI, John A., Causality Between Direct Foreign Investment and Economic Output in Ghana, Journal of Economic Development, 1992, 17(1), s. 7-17.

KAYA, Vedat, YILMAZ, Ömer, Türkiye’de Doğrudan Yatırımın Belirleyicileri, Atatürk Üniversitesi İIBF Dergisi, 2003, 17 (3-4), s. 39-56.

KURTARAN, Ahmet, Doğrudan Yabancı Yatırım Kararları ve Belirleyicileri, Atatürk Üniversitesi Sosyal Bilimler Enstitüsü Dergisi, 2007, 10(2), s. 367-382.

LUCKE, Navina, EICHLER, Stefan, Foreign Direct Investment: the Role of Institutional and Cultural Determinants, Applied Economics, 2016, 48(11), s. 935-956.

MONTEIRO, Carlos A., MOURA, Erly C., CONDE, Wolney L., POPKIN, Barry M., Socioeconomic Status and Obesity in Adult Populations Of Developing Countries: A Review, Bulletin of the World Health Organization, 2004, 82(12), s. 940-946.

MORISSET, Jacques P., Does a Country Need Promotion Agency to Attract Foreign Direct Investment?, World Bank Policy Research Working Paper, 2003, No. 3028.

OKEREKE, Emeka JUDE, Ebulison, Nelson Okheshimi, Determinants of Foreign Direct Investment Inflows in Nigeria: An Empirical Analysis (1970-2011), 2016, Available at SSRN 2756975.

OKTAR, Suat, YÜKSEL, Serhat, Bankacılık Krizlerinin Erken Uyarı Sinyalleri: Türkiye Üzerine Bir Uygulama, İstanbul Ticaret Üniversitesi Sosyal Bilimler Dergisi, 2015, 14(28), s. 37-53.

OKTAR, Suat, YÜKSEL, Serhat, Bankaların Türev Ürün Kullanımını Etkileyen Faktörler: MARS Yöntemi ile Bir İnceleme. Finans Politik \& Ekonomik Yorumlar, 2016, 53(620), s. 31-46.

OKYAR, Osman, Development Background of The Turkish Economy, 1923-1973, International Journal of Middle East Studies, 1979, 10(3), s. 325-344.

ÖZAĞ, Filiz, Ev Sahibi Ülke Açısından Yabancı Sermaye Yatırımlarını Etkileyen Faktörler ve Türkiye Üzerine Bir Uygulama, Ekonomik Yaklaşım Dergisi, 1994, 5 (12), s. 63-77.

PAMUK, Şevket, Economic Change in Twentieth-century Turkey: Is The Glass More Than Half Full?, The American University of Paris, 2007, s. 2-32. 
QUAZİ, Rahim M., Corruption and Foreign Direct Investment in East Asia and South Asia: An Econometric Study, International Journal of Economics and Financial Issues, 2014, 4(2), s. 231.

SALEM, Mohamed, BAUM, Andrew, Determinants of Foreign Direct Real Estate Investment in Selected MENA Countries, Journal of Property Investment \& Finance, 2016, 34(2), s. 116-142.

SARAY, M. Ozan, Doğrudan Yabancı Yatırımlar-İstihdam İlişkisi: Türkiye Örneği, Maliye Dergisi, 2011, 161, s. 381-403.

SARISOY, İdris, KOÇ, Selçuk, Doğrudan Yabancı Sermaye Yatırımlarının Kurumlar Vergisi Gelirleri Üzerindeki Etkisinin Ekonometrik Analizi, Erciyes Üniversitesi İktisadi ve İdari Bilimler Fakültesi Dergisi, 2010, (36), s. 133-153.

SCHNEIDER, Friedrich, FREY, Bruno S., Economic and Political Determinants of Foreign Direct Investment, World Development, 1985, 13 (2), s. 161-175.

SEPHTON, Peter, Forecasting Regressions: Can We Do Better on MARS?, Federal Reserve Bank of St. Louis Review, 2001, 1, s. 39-49.

STORPER, Michael, The Limits to Globalization: Technology Districts and International Trade, Economic Geography, 1992, 68(1), s. 60-93.

TEKİN, Hatice Armutcuoğlu, ŞANLISOY, Selim, Yabancı Patentlerin Doğrudan Yabancı Sermaye Yatırımları Üzerindeki Etkisi: 1974-2012 Türkiye Örneği, Kafkas University. Faculty of Economics and Administrative Sciences Journal, 2016, 7(12), s. 65-88.

TERZİ, Harun, Günaydın, İhsan, Ekonomik Kalkınmada Doğrudan Yabancı Sermaye Yatırımlarının Rolï: Türkiye Açısından Bir Değerlendirme, İktisat İşletme ve Finans Dergisi, 1997, 12 (132), s. 52-61.

TSAI, Pan-Long, Determinants of Foreign Direct Investment in Taiwan: An Alternative Approach With Time-Series Data, World Development, 1991, 19(2-3), s. 275-285.

TUNAY, Kaşif Batu, Bankacılık Krizlerinin Erken Uyarı Sinyalleri: Türkiye İçin Bir Model Analizi, BDDK Bankacılık ve Finansal Piyasalar Dergisi, 2010, 4, s. 9-46.

TUNAY, Kaşif Batu, Türkiye'de Durgunlukların MARS Yöntemi ile Tahmini ve Kestirimi, Marmara Üniversitesi İ.İ.B.F. Dergisi, 2011, 30, s. 71-91.

TUNAY, Kaşif Batu, Türkiye’de Paranın Gelir Dolaşım Hızlarının MARS Yöntemiyle Tahmini, ODTÜ Gelişme Dergisi, 2001, 28(3-4), s. 175-197.

UDENZE, Oyinye, The Effect of Corruption on Foreign Direct Investments in Developing Countries, The Park Place Economist, 2014, Vol. 22, s. 87-95.

YAVAN, Nuri, KARA, Hamid, Türkiye'de Doğrudan Yabancı Sermaye Yatırımları ve Bölgesel Dağılışı, Coğrafi Bilimler Dergisi, 2003, 1(1), s. 19-42.

YÜKSEL, Serhat, Türkiye’de Cari İşlemler Açığının Belirleyicileri: MARS Yöntemi ile Bir İnceleme, Bankac1lar Dergisi, 2016, 96, s. 102-121.

YÜKSEL, Serhat, ZENGİN, Sinemis, Leading Indicators of 2008 Global Crisis: An Analysis with Logit and MARS Methods, Finansal Araştırmalar ve Çalışmalar Dergisi, 2016, 8 (15), s. 495-518

ZURAWICKI, Leon, HABİB, Mohsin, Corruption and Foreign Direct Investment: What Have We Learned?, The International Business \& Economics Research Journal, 2010, 9(7), s. 1-9. 